\title{
Influence of Entrepreneurial Education and Attitude on Entrepreneurial Intention of Graduating Students in a Nigerian University
}

\author{
Saifullahi Adam Bayero \\ Department of Business Administration, Federal University, Gashu'a, Nigeria
}

\begin{abstract}
This study assessed the influence of entrepreneurial education (EE) and entrepreneurial attitude (EA) on the entrepreneurial intention (EI) of graduating students in a Nigerian university. Through a descriptive quantitative methods, questionnaires were distributed and retrieved from a total of 157 non-probabilistic convenience samples from the final year students across the different faculties of Bayero University, Kano (BUK). To test the proposed hypotheses, the Partial Least Squares Structural Equation Modeling (PLS-SEM) was employed. The results showed that EE and EA have strong influence on the EI of the graduating students. Similarly, the measurement model confirmed reliability and validity of all indicators using the convergent and discriminated validity using 5000 bootstrapping algorithm re-sampling technique. The structural model also validated the two hypothesized relationships among the variables of the study. The results have enormous implications to both the academic community and the government.
\end{abstract}

Keywords: entrepreneurial intention, attitude, entrepreneurial education, university graduate

Suggested citation: Bayero, S. A. (2020). Influence of Entrepreneurial Education and Attitude on Entrepreneurial Intention of Graduating Students in a Nigerian University. International Journal of Academe and Industry Research, Volume 1, Issue 2, pp. 26 - 55.

\section{Introduction}

Entrepreneurship is irrefutably considered important to economic transformation, growth and development (Anjum, Ramani \& Phung, 2020; Caballero-García, Guillén, \& Martínez, 2017; Edewor Imhonopi,\& Amusan, 2014; Keilbach, Tamvada, \& Audretsch, 
2008; Mamun \& Fazal, 2019; Mamuzo \&akpor-robaro, 2012; Oluwale, Olaposi, Adelowo, \& Akangbe, 2016; Pantelitsa, Ariana, Marios, \& George, 2018; Pradhan \& Nath, 2012; Rasheed \& Aduragbemi, 2016; Silangen \& Patricia, 2016; vixathep, 2014; Williams, Vorley, \& Ketikidis, 2013; Zeleam, Temtime, \& Pansiri, 2004) especially for any country facing colossal challenges of economic meltdown, poverty and unemployment (Agbo,Nzeadibe, \&Ajaero, 2012; Alabi, Aderinto, David, 2019; Beeka, 2015; Iwelumo, 2018; Lawal \& Oluwatoyin, 2011; Obisi \& Gbadamosi, 2016; Odii \& Njoku, 2013; Ohanu \& Ogbuanya, 2018; Olukayode, 2014; Onodugo \& Onodugo, 2015; Sanusi, 2010) such as Nigeria (Audretsch, 2007; Singer et al., 2015). The introduction of entrepreneurial education (EE) in the university curriculum for the purpose of promoting entrepreneurial spirit to the university students is done to stave off the lack of employable skills and job among graduates (Adu, Boakye, Suleman \& Bingab, 2020). Despite this, there has been an increase in the number of unemployed university graduates in Nigeria. As a matter of fact, entrepreneurship proved to be the lasting solution to that problem (FragosoRocha-junior \& Xavier, 2019; Kim-soon, Ahmad \& Ibrahim, 2014). Studies established that most of the African youths have positive attitudes, entrepreneurially active and ready to take risks (Adebayo \& Kavoos, 2016). Many countries, including Nigeria, have learned from the success of American students in entrepreneurship (Zhao, Wei, Chen \& Yien, 2020). This ushered in the re-appreciation of the university role of producing entrepreneurially active graduates as well as scrapping the idea of teaching student as future employees. For this reason, entrepreneurship is now considered a career option for most university students (Mamun, Nawi, Dewiendren \& Shamsudin, 2016; Moraes, Iizuk a \& Pedro, 2018; Velásquez, Arias, Hernández, Díez-echa, Marín, Pérez, 2017).

Research suggests that entrepreneurial intention (EI) is a crucial step in the business creation process and an indicator of business performance (Radipere \& Ladzani, 2014; Tiwari, Bhat, \&Tikoria, 2020). EI is the intention of a person to start a new business (Kela, Icekson \& Peres, 2019; Saraih, Ibnu, Ali \& Mohd Suffian, 2019). This intention is seen as a predictor of a person who will engage to something unpredictable which results to a new business venture (Fini, Marzocchi, \& Sobrero, 2009).

Researchers in the field of entrepreneurship identified various determinants of individual EI (Norashidah \& Hussain, 2015). Relative to an effective design of education 
initiative, they should identify which elements play the most important role in framing an individual decision to start a business (Liñán, Rodríguez, \& Rueda-Cantuche, 2011). In an attempt to understand factors responsible for entrepreneurship undertaking, many researches were conducted several decades ago (Wyk, Boshoff \& Bester, 2003). In addition, Iakovleva, Shirokova and Tsukanova (2014) concurred with the need to study factors responsible for EI. Several researchers also recommended further studies on EI in various geographical settings to include students from different countries while others affirmed on the need to increase sample size in different university settings (Hong, Sha'ari, Wan \& Che, 2020; Law \& Breznik, 2016; Patrisia \& Abror, 2019) and suggested to capture more factors and scope (Ezeh, Nkamnebe \& Omodafe, 2019). Despite a number of research were published, Anjum, Ramzani, Farrukh, Nazar, Raju and Shahzad, (2018) still believe that there is limited research in developing countries to fully comprehend the relationship between EE and EI.

There are only few studies conducted on EI in Nigeria. It is apparent that there have been relatively few empirical studies of its impact, distinct from that of general education, on perceptions of entrepreneurship and EI (Krueger \& Brazeal 1994; Peterman \& Kennedy 2003). This study aims to bridge those research gaps. The primary objective of this study is to examine the influence of EE and entrepreneurial attitude (EA) on EI of graduating students in a Nigerian university.

\section{Literature Review}

\subsection{Entrepreneurial intention}

Being an essential theme in entrepreneurship, EI proved to be the best predictor of planned behavior (Hong, et al., 2020; Norziani, Mastura \& Rosdi, 2015; Nuseir, Basheer \& Aljumah, 2020). It comprises the intention and commitment of a person to launch new business venture (Purwana, Suhud \& Wibowo, 2018) in an innovative way (Chienwattanasook, Jermsittiparsert \& Jarinto, 2019). It therefore involves looking at the desirability and feasibility of a business idea and finds out the important cause of business formation (Massaro, Mas, Garlatti \& Paschetto, 2015). According to Kusmintarti, Asdani and Riwajanti, (2017), it is a cognitive representation of actions to be performed by an individual for the purpose of setting up one or more new businesses. Ahmed, Pahi, Mozammel and Mozammel, (2018) add that it can also be seen as how keen or engrossed an individual is in 
prototypical entrepreneurial activities, or in a period to which a person is committed to starting his own business. EI can also be seen as a mindful condition of the mind that route attention, experience and action toward a precise object (goal) or the path of achieving it. Whereas, according to Bose and Uddin, (2012) it is the appetite of starting a new business. Paço, Ferreira, Raposo, Rodrigues and Dinis, (2013) are in the view that appreciating factors responsible for shaping students' intentions to start their own businesses is very important for developing an achievable programs and policies necessary to promote entrepreneurial behavior.

\subsection{Entrepreneurial education and entrepreneurial intention}

Education plays a momentous contribution in widening students' knowledge and skills as well as increasing the possibility of the students to be employed after graduation (Bazkiaei et al., 2020). Researchers considered EE as the most important factor to determine a person's intention to become an entrepreneur (Adu, Boakye, Suleman \& Bingab, 2020). It is also regarded as a 'weapon' for living in a modern world. For this reason, some researchers and policy makers placed EE and associated programs on their priority agenda (Adetola, Shamsudin \& Minai, 2018).

The main objective of the EE adoption in the university curriculum is to arm the students with the necessary entrepreneurial skills (Adelaja, Umar, Soomiyol, Ahmad, Najeemdeen \& Abidemi, 2018) to run a successful business, and to improve their entrepreneurial aptitude (Gubik \& Farkas, 2019). When individuals learn about entrepreneurship, they will regard it as a professional option (Ramos, Madeira \& Duarte, 2020). In addition to the contribution to knowledge, EE also empowers people with the analytical skills and knowledge of entrepreneurial process enabling them to discover feasible business opportunities, mobilize and organize resources for the actualization of the business and develop strategy to explore the opportunity (Viana, Carvalho \& Cândido, 2019).

More recent research by Boldureanu, Ionescu, Ionescu, Boldureanu, Bedrule-grigorut and Boldureanu, (2020), Hong, Hassan, Zulkiffi, Aziz and Isma'il, (2020), Mlouk, Cera, Cera and Shumeli,(2020) and Saleem and Khan, (2020) showed a positive significant relationship between EE and EI. Additionally, the studies of Asimakopoulos, Hernández and Miguel, (2019), Hussain and Hashim, (2015), Jermsittiparsert and Sriyakul, (2019), Khalifa and 
Dhiaf, (2016), Li and Wu, (2019), Lin and Sang, (2019), Mamun, Shamsudin, Nawi, Nasi and Zakaria, (2017), Odor, Martins-Emesom and Bakwuye, (2019), Passaro, Quinto and Thomas, (2018), Soomro, Memon and Bukhari, (2019), Sopta, Mikić and Horvatinović, (2018) and Sultan, Maqsood and Shrif, (2019) also found a positive relationship between EE and EI.

Studies confirm that there is significant theoretical and empirical link between EE and EI (Khalifa \& Dhiaf, 2016; Mei, Lee \& Xiang, 2020). For example, studies by Carrillo and Montiel, (2020), Saraih and Ali, (2019), Sultan, Maqsood and Shrif, (2019) all shown a positive relationship between EE and EI. Similarly, Adetola and Minai, (2018), Alshebami, Al-jubari, Alyoussef and Raza, (2020), Amaliawati, Martono, Dyah and Indrawati, (2019), Doan and Phan, (2020), Liu, Lin, Zhao and Zhao, (2019), Pulka et al., (2015), Purwana and Suhud, (2019) and Voda, Covatariu and V, (2019) have all found that EE has a significant effects on the EI of the university students. Based on these findings, the present study posits that:

H1: Entrepreneurial education has a significant positive influence on entrepreneurial intention.

\subsection{Right entrepreneurial attitude and entrepreneurial intention}

Esfandiar, Shari, Pratt and Altinay, (2019), said attitude is a "psychological tendency that is expressed by evaluating a particular entity with some degree of favor or disfavor." The more positive the attitude toward entrepreneurship is, the more student will be encouraged in venturing into business. Attitude can be seen as an evaluation of an object of thought (Abdul-mohsin, Ahmad \& Abdul-Halim, 2015) which shows how an individual mind respond to object and affects the behavior. Relatively, it is an evaluation of cognitive and emotional feelings towards an object (Ruswanti, 2015). Ismail, (2015) said "attitudes and intentions are precursors of entrepreneurial action, an understanding of the attitudes, and those factors which may impact them is a critical step in promoting greater entrepreneurial initiatives."

In this context, the attitude towards entrepreneurship is the extent to which an individual has a welcome or unwelcome and good or bad appraisal of the entrepreneurial behavior (Pulka, Aminu \& Rikwentishe, 2015). Relatively, Kakkonen, (2018) explains that 
EA is about knowing what it means to be an entrepreneur with a tendency towards entrepreneurial behavior or self-employment. The measures of EA include achievement, innovation, personal control, self-esteem, and opportunity recognition (Lindsay, 2005). In most instances, people develop a positive attitude towards something if they will benefit when they do it and vice versa. Thus, students tend to admire entrepreneurship if they expect benefits from it (Kusmintarti, Thoyib, Ashar \& Maskie, 2014).

The studies conducted by Abun, Foronda, Agoot, Belandres, and Magallanez (2018), Abun, Foronda, Agoot, Belandres and Magallanez (2018), David and Lawal (2018), Esfandiar, Shari, Pratt and Altinay (2019), Gujrati, Tyagi and Lawan (2019), Liu., Lin, Zhao and Zhao (2019), and Norziani, Mastura and Rosdi (2015) all found that EA has a significant effects on the EI of university students. It was further disclosed in the study of Pulka et al. (2015) that EA is a good predictor of EI. This was supported by the same results generated from the studies of Law and Breznik, (2016), Leng and Buang (2019) and Tung (2011). Based on these empirical evidence, the present study posits that:

H2: Entrepreneurial attitude has a significant positive influence on entrepreneurial intention.

\section{Methodology}

This study is descriptive in nature. Through the use of adopted questionnaires, the data were analyzed to determine the effect of EE and EA on the EI of the graduating students in a Nigerian University.

\subsection{Research instruments}

The study adopted three questionnaires to measure EE, EA and EI of the participants. The scale of EE measurement was adapted from the study of Njambi (2016) while the scales of EA and EI were adapted from Luthje and Franke (2003) and Robledo, Luis, Arán, Sanchez, Victor and Molina (2015), respectively. Overall, the constructs have 19 items which include EE (10 items), EA (3 items) and EI (6 items). The measurement used a 5point Likert scale with options ranging from strongly agree (1) to strongly disagree (5). 
The survey was administered by the researchers which was restricted to the final year students of Bayero University, Kano.

\subsection{Sample design and data collection}

In most research situations, it would be excellent to use the entire population but it is unthinkable. Thus the use of sampling techniques like convenience sampling arises (Etikan, Musa, \& Alkassim. 2016). The main data collection involved the distribution of 250 selfadministered questionnaires to final year undergraduate students across six faculties including Management Sciences, Social Science, Education, Agriculture, Engineering and as Art and Islamic at Bayero University, Kano (BUK). BUK has more than 34,895 enrolled undergraduate students with around 5,000 students in their final year in the 12 academic faculties that constituted 74 Departments. A non-probabilistic convenient sampling technique was used in this study which according to Matamanda and Chidoko (2017) is the most suitable sampling method as it is affordable, easy and generates no difference in the results obtained from a random sample. Similarly, it is most frequently used in quantitative studies (Etikan et al., 2016).

Cooper and Schindler (2008) noted that 5\% is acceptable sample size. For this study, the estimated population of the final year undergraduates in BUK is 5,000 which means the target sample size is 250 respondents (i.e., 5,000 X 0.05). Of the total sample size surveyed, 157 were properly filled out and returned generating a response rate of $62.8 \%$. Humphrey (2015) and Hwingwiri (2013) noted that a response rate of 50\% is considered to be adequate, $60 \%$ to be good, $70 \%$ as very good and a response rate above $80 \%$ considered excellent. Relatively, Hair, Black, Babin, \& Anderson (2010) and Sekaran (2003) stressed that a 30\% response rate is acceptable for survey studies.

\section{Findings and Discussion}

\subsection{Data analysis}

The Smart PLS version 3 was used to analyze the data collected for this study because it has a concern on data normalcy and sample size as well as accommodating the reflective and formative constructs (Chin, 1998). At the same time, it also evaluates the relationship between the measurement model and the structural model as the two basic steps 
concurrently (Anderson \& Gerbing, 1988). It gives an avenue for measurement of latent variables and the required indicators necessary for the statistical measurement (Hair, Hult, Ringle, \& Sarstedt, 2014). According to Muhammad et al., (2017), reflective measurement model involves three basic validities: indicator loadings, internal consistency, and convergent and discriminant validity.

\section{Figure 1}

The measurement model

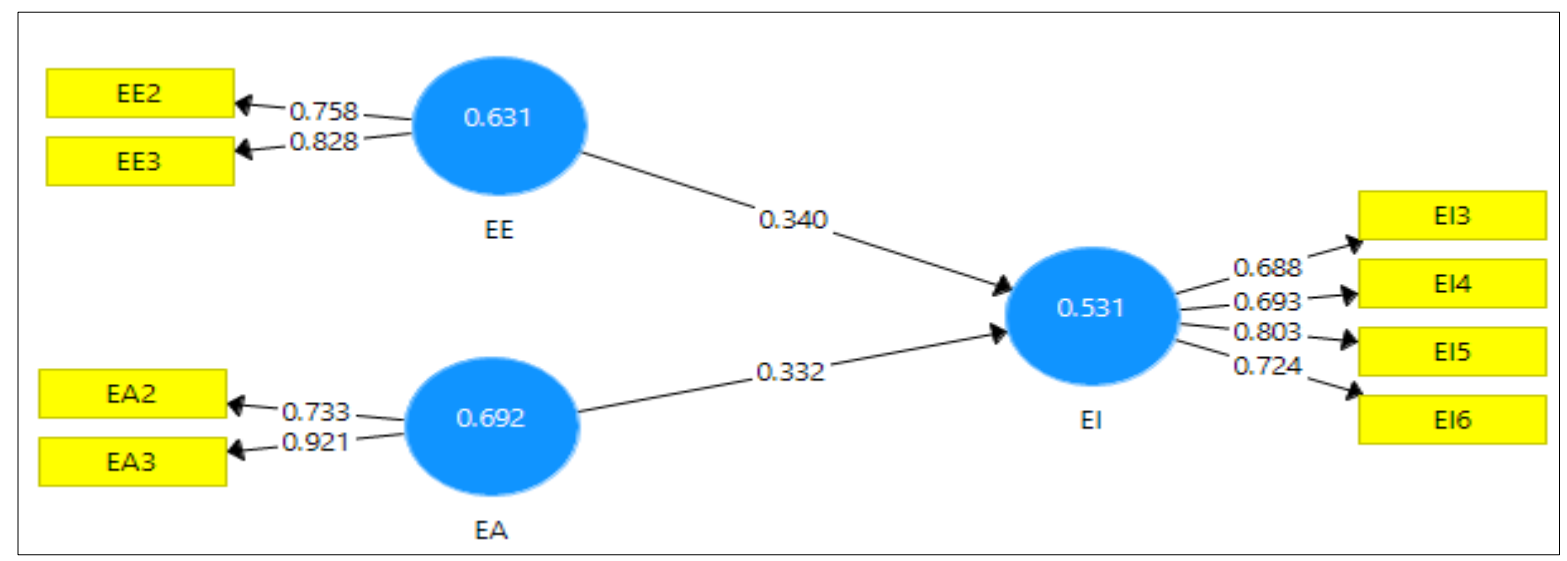

The process of obtaining and testifying the result to go along with the designed theories is what Sekaran and Bougie (2013) referred to as construct validity. Relatively, Hair, Black, Babin, Anderson, and Tatham (2010) also confirmed that individual loadings are used to determine the validity of the measurement model. Most of the individual item loadings as indicated in the table 1 are above 0.7, which is above a threshold of 0.7 (Hair et al., 2014). It is accepted because they lead to the achievement of Composite Reliability (CR) and Average Variance Extracted (AVE). Likewise, the convergent validity of the model was also established in accordance with Chin (2010) and Hair, Anderson, Tatham, and Black (1998) suggestions that values of the CR must be above 0.70 to be accepted (see table 1). The table 1 also indicates that AVE values are all above the threshold of 0.50 as suggested by Henseler, Ringle, \& Sinkovics (2009). 
Table 1

Factor loadings, composite reliability and average variance extracted

\begin{tabular}{lllcc}
\hline \multicolumn{1}{c}{ Constructs } & \multicolumn{1}{c}{ Items } & Loadings & CR & AVE \\
\hline Entrepreneurial Attitude (EA) & EA2 & 0.733 & 0.816 & 0.692 \\
& EA3 & 0.921 & & \\
\hline Entrepreneurial Education (EE) & EE2 & 0.758 & 0.773 & 0.631 \\
& EE3 & 0.828 & & \\
\hline Entrepreneurial Intention (EI) & EI3 & 0.688 & 0.818 & 0.531 \\
& EI4 & 0.693 & & \\
& EI5 & 0.803 & & \\
& EI6 & 0.729 & & \\
\hline
\end{tabular}

The study also tested discriminant validity using Fornell and Larcker (1981) criteria. According to them, discriminant validity explains the degree to which items differentiate among constructs or measure distinct concepts. The values in table 2 show that the most conventional approach in assessing discriminant validity is Fornell-Larcker Criterion (Ibrahim \& Shariff, 2016). From this view, the discriminant validity was assessed by comparing the square root of AVE for each construct with the correlations presented in the correlation matrix. The table 2 shows the results of Fornell-Larcker criterion assessment with the square root of the constructs. The AVE in bold is greater than its highest construct's correlation with any other constructs. Thus, it can be concluded that discriminant validity on the construct has been established.

In addition, Henseler, Ringle, and Sarstedt (2015) argued that the Fronell-Lacker's criteria sometimes fail to detect discriminant validity, as such becoming unreliable especially in common research situations. For this reason, Henseler et al. (2015) suggested the multitrait-multimethod matrix as the other way of evaluating discriminant validity by using the heterotrait-monotrait (HTMT) ratio of correlations. In line with this argument, the study achieved discriminant validity as none of the values exceeded HTMT 0.85 as shown in Table 2. Specifically, the model provided complete measurement validity that included individual item reliability, internal consistency, convergent validity and discriminant validity. 
Table 2

Discriminant validity

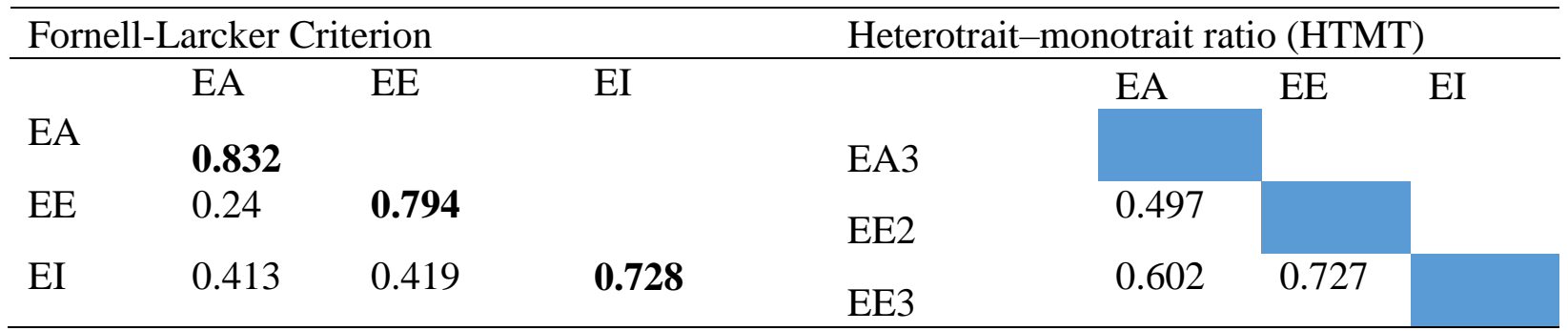

The study fully conducted all the necessary tests to ensure a fit and satisfactory measurement model as identified above. This is followed by the estimation of the structural model parameters to determine R2, path coefficient, effect size (F2) and model fit using predictive relevance $(\mathrm{Q} 2)$. In estimating the above criteria, the study utilized the 5000 bootstrapping algorithm resampling technique (Hair, Ringle, \& Sarstedt, 2011).

\subsection{Structural model}

There are four key criteria for assessing the structural model in Smart PLS SEM. These include assessments of: (1) significance of the path coefficients, (2) coefficient determination $\left(R^{2}\right),(3)$ the effect size $\left(f^{2}\right)$, and lastly (4) predictive relevance $\left(Q^{2}\right)$. The results for the assessment of the significance of path coefficients (Henseler et al., 2015; Ibrahim \& Mas'ud, 2016) are presented in Figure 2 and Table 3, respectively. Reliable and valid outer model estimation permits an evaluation of the inner path model estimates. Chin (1998) describes $\mathrm{R}^{2}$ values of $0.67,0.33$, and 0.19 in PLS path models as substantial, moderate, and weak, respectively. If certain inner path model structures explain an endogenous latent variable by only a few (e.g., one or two) exogenous latent variables, "moderate", R2 may be acceptable (Ringle \& Sinkovics, 2009).

Ibrahim and Shariff (2016) observe that the techniques for assessing mediation are numerous but the most recent approach is the bootstrapping method which generates an empirical representation of the distribution of the sample of the indirect effect. The main advantage of bootstrapping approach is that it does not require any assumptions about the sampling distributions of the indirect effect or its product. 
Figure 2

The structural model

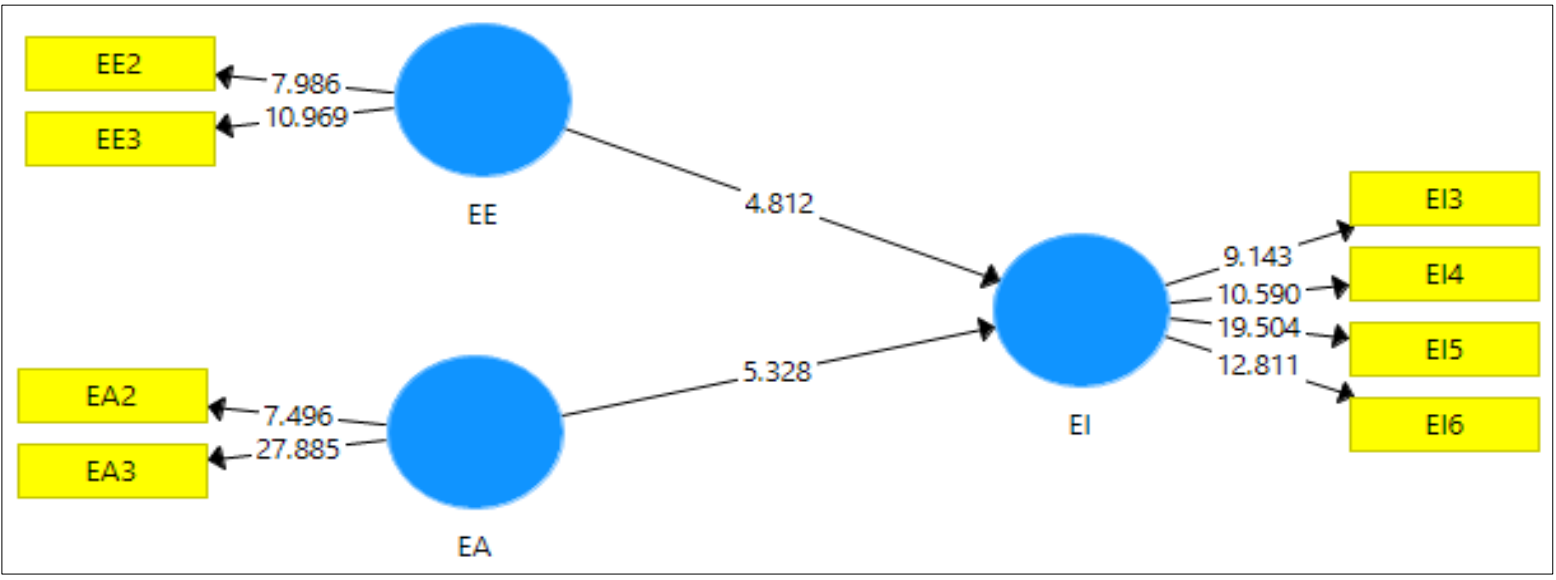

The structural model in figure 2 presents a path model with two direct effects EE->EI and EA->EI. Evaluation of the structural path model is presented in table 5.

Table 3

Coefficient Determination (R2)

\section{R Square $\quad$ R Square Adjusted}

EI

0.28

0.27

The structural model concerns with creating the link between and among constructs of the study through path coefficient while the $\mathrm{R}^{2}$ evaluates the explanatory power of the exogenous variables in explaining the endogenous variables (Ibrahim, Mahmood, \& Bakar, 2018). This also explains the fundamental relationship that exists between the constructs of the study. The variance $\left(\mathrm{R}^{2}\right)$ and the path coefficient are the main process in which the hypothesis of the study are justified (Chin, 1998). The R Square and R Square Adjusted show how well combination of independent variables predicts the dependent. The coefficient determination $\left(\mathrm{R}^{2}\right)$ of the model is 0.28 which implied that EE and EA collectively explained $28 \%$ of the changes in EI. In relation to this, Chin, (1998) categorized R-square of 0.19, 0.33 and 0.67 as weak, moderate and substantial, respectively. Thus $\mathrm{R}^{2}$ of this research can be considered moderate. 
Table 4

The effect size $\left(f^{2}\right)$

EA EE $\quad$ EI

EA

EE

EI

\subsection{4}

0.151

Another criterion for evaluating a structural model is through the effect-size $\left(\mathrm{f}^{2}\right)$ (Ibrahim \& Mas'ud, 2016). The $\mathrm{f}^{2}$ determines the effect of each variables on dependent variable. For this study, $\mathrm{f}^{2}$ proved EE has $15 \%$ influence on EI while EA has $14 \%$ influence on EI. Both independent variables are said to be significant determinants of the dependent variable. Ringle and Sinkovics (2009) noted that values of 0.02, 0.15, and 0.35 can be viewed as a gauge for whether a predictor latent variable has a weak, medium or large effect at the structural level. For this research, the effect size $\left(\mathrm{f}^{2}\right)$ is moderate.

\section{Table 5}

Path Coefficients for Hypotheses Testing

\begin{tabular}{ccccc}
\hline Hypothesis & Beta & T Statistics & P Values & Decision \\
\hline EA -> EI & 0.329 & 5.311 & 0.000 & Accepted \\
EE -> EI & 0.335 & 4.772 & 0.000 & Accepted \\
\hline
\end{tabular}

This study tested the influence of EE and EA on the EI of the graduating students in a Nigerian university using the Smart PLS 3.0 with 5,000 sub- samples. The interpretation and summary of the results is presented in table 5 by using P-values, T-statistics, and Beta. The result indicated a positive relationship between the independent variables and the dependent variable. It is clear from table 5 that $\mathrm{EE}$ and $\mathrm{EA}$ have direct influence on EI of graduating students. The result of the relationship between $E E$ and $E I$ is $\beta=0.335 ; t=4.772 ; p=0.000$ and that of the relationship between EA and $\mathrm{EI}$ is $\beta=0.329 ; \mathrm{t}=5.311 ; \mathrm{p}=0.000$.

On the relationship between EE and EI, the result revealed that $(\beta=0.335 ; \mathrm{t}=4.772$; $\mathrm{p}=0.000$ ) the more university students have access to quality $\mathrm{EE}$, the more their intention to venture into a new business would increase by 34 percent thereby supporting $\mathrm{H} 1$ that EE has 
a significant positive influence on entrepreneurial intention. The result is congruent with the previous studies of Carrillo and Montiel (2020), Saraih and Ali (2019) and Sultan, Maqsood and Shrif (2019) which all shown positive relationship between EE and EI. To this effect, if the Nigerian government and the universities want to enhance graduating students' intention to start their own entrepreneurial undertaking, they should focus on imparting a quality entrepreneurial education to the students. The current study reflects a $34 \%$ increase in the number of Nigerian students who will probably venture into a new business after a quality entrepreneurial education which will contribute a lot in staving off the endemic soaring unemployed graduates in Nigeria. EE has been a significant step in the development of the Nigerian university students' entrepreneurship success through their involvement in entrepreneurial activities that increase intention and penchant to start their own business. Truly, universities are not only established to produce graduates but to provide a degree that enables students to face the challenges in the community and the world, in general. In other words, universities must improve the skills of the graduates through entrepreneurial education.

On the part of the EA and EI, result $(\beta=329 ; \mathrm{t}=5.311 ; \mathrm{p}=0.000)$ indicated that the more university students develop positive attitude toward entrepreneurship, the more their EI increase by 33 percent. Hence, it supports $\mathrm{H} 2$ that EA has a significant positive influence on EI. The result is also congruent with the findings of Law and Breznik (2016), Leng and Buang (2019) and Tung (2011). In order to enhance EI, efforts should mount to inculcate the attitude of entrepreneurship to the Nigerian university students. This positively increases their intention to start their own business venture after graduation and will also contribute in controlling the towering number of unemployed graduates in the country. In addition, the result also proved that students' EA strongly contributes to their EI. Therefore, the focus must be on the entrepreneurial personality development through providing practical and influential course experience such as success stories of business owners. This will eventually embolden their EI in business development and entrepreneurial undertaking after graduation. The domino effect to taking life opportunities, students will perceive entrepreneurship as a ladder to their goals, aims and objectives which will result to a burning positive attitude and desire towards entrepreneurship. 
In the same vein, entrepreneurship is considered as an engine of economic development which should be at the center of any country's national policy. It is imperative to analyze individual behavior in starting a new business venture (Rodrigues, Marques \& Geraldes, 2020). It is becoming clear that through EE, the mindset of the students can be changed to embrace entrepreneurship. Thus, quality EE must be a priority of universities. Through a linear equation, the EE develops EA to increase EI.

\section{Table 6}

The predictive relevance $\left(Q^{2}\right)$

\begin{tabular}{cccc}
\hline & SSO & SSE & $\mathbf{Q}^{2}$ (=1-SSE/SSO) \\
\hline EA & 312 & 312 & \\
EE & 312 & 312 & \\
EI & 624 & 546.811 & 0.124 \\
\hline
\end{tabular}

The structural model can also be established using cross-validated redundancy measure $\mathrm{Q}^{2}$ which allows for assessing the model predictive relevance. In addition, changes in $\mathrm{Q}^{2}$ allow assessing the relative impact of the structural model for predicting the observed measures of an endogenous latent variable by the $\mathrm{Q}^{2}$ effect size (Chin, 1998; Ringle et al., 2012). If this value for a certain endogenous latent variable is larger than zero, its explanatory variables provide predictive relevance (Ringle \& Sinkovics, 2009). The Q2 was established through blindfolding. The new predictive relevance (Q2) values as presented in table 6 are all positive. This indicates that the model has predictive relevance (Chin, 1998).

\section{Conclusion and Implication of the study}

This study examined the influence of EE and EA on EI of graduating students in a Nigerian university. As the main motivation of the authors to provide solution to the rising number of unemployed graduates in the country, the study provides a quantitative approach to identifying the predictors of EI. Although several studies have been conducted in different countries, the current study fills the gap in Nigeria. This study attempts to increase the understanding of the relationship that exist between EE and EA on the EI of students. 
The findings of this study support all the postulated hypotheses which indicate that developing EI among university students is far beyond just policies and programs. There are also other critical factors such as EE and EA. In particular, the tested positive relationships between EE, EA and EI were all affirmed. The findings of the study also support previous studies that established a positive relationship between EE and EI (Boldureanu, et al., 2020; Silangen \& Harapan, 2016; Tung, 2011; Zhang, Duysters \& Cloodt, 2014). Similarly, the second hypothesis provided a statistically significant and positive relationship between EA and EI. This is relative to the previous studies (Law \& Breznik, 2017; Leng \& Buang, 2019; Tung, 2011) in which EA was found to be a key determinant of EI among university students.

The present study has numerous implications to both the academic community and the government. Firstly, the results bring into light the importance of EE and EA as a predictors of students' intention to engage themselves in entrepreneurial activities. Secondly, through the link that EE influences individual EI, it is made clear that entrepreneurs can be made. This is evident through EE wherein developments of entrepreneurial skill, knowledge and talent are apparent. As such, it is imperative for the academic community to develop and update university curriculum including the sound entrepreneurial education and training attuned with the dynamic nature of today's environment and enabled the knowledge sharing to enhance EE and EA. Thirdly, as the results show a cross-sectional effect, a dynamic support system in entrepreneurial development must be looked into. For instance, entrepreneurial development centers would be of great importance to be established either by the federal, state or local governments. This can provide support as well as practical education to students to develop their mindset and attitude toward self-reliance and entrepreneurship. Lastly, the wider implication of the study calls for sustainable stakeholder partnership. Since most of the Nigerian universities are funded by government, collaborations and partnerships between government and universities is the key to ensure success in promoting EE and EA.

Despite the study's contribution to knowledge, there exist some limitations. The data were collected only at Bayero University, Kano during a specific time period with a limited number of samples. Therefore, future researchers should look into the possibility of crossexamination among other universities in different countries. It is also imperative that further 
studies consider the use of larger cross-cultural samples to enhance the generalizability of the findings. As the current study used convenience non-probability sampling, probability sampling technique may also be considered. These are important points in identifying the level of the EI in order to establish the proper entrepreneurial courses and skills programs required.

\section{References}

Abdul-mohsin, A. M., Ahmad, N. H., \& Abdul-Halim, H. (2015). Competitive Intelligence Among SMEs: Assessing the Role of Entrepreneurial Attitude Orientation on Innovation Performance . 2nd International Symposium on Partial Least Squares Path Modeling, Seville (Spain), 1-12.

Abun, D., Foronda, S. L. G. L., Agoot, F., Belandres, M. L. V, \& Magallanez, T. (2018). Entrepreneurial attitude and entreprenurial behavior Measuring entrepreneurial attitude and entrepreneurial intention of ABM grade XII , Senior High School Students of Divine Word Colleges in Region I, Philippines. International Journal of Applied Research, 4(4), 100-114.

Adebayo, G. S., \& Kavoos, M. (2016). The Present Attitude of African Youth Towards Entrepreneurship. International Journal of Small Business and Entrepreneurship Research, 4(1), 21-38.

Adelaja, A. A., Umar, M. A., Soomiyol, M. T., Ahmad, R., Najeemdeen, I. S., \& Abidemi, B. T. (2018). Effectuation Approach in Accessing Entrepreneurial Education Significance on Students Entrepreneurial Intention. Indian-Pacific Journal of Accounting and Finance (IPJAF), 2(4), 35-43.

Adetola, A. A., \& Minai, M. S. (2018). Students entrepreneurial intention changes due to entrepreneurial education exposure: The experimental design approach. Journal of Entrepreneurship Education, 21(4), 1-12. https://doi.org/10.13140/RG.2.2.35573.83688

Adetola, A. A., Shamsudin, A. S., \& Minai, M. S. (2018). Conceptualizing The Effect of Entrepreneurial Education and Industrial Interface Mix in Enhancing The Entrepreneurial Intention Amongst. Journal of Entrepreneurship Education, 21(3), 19. 
Adu, I. N., Boakye, K. O., Suleman, A., \& Bingab, B. B. B. (2020). Exploring the factors that mediate the relationship between entrepreneurial education and entrepreneurial intentions among undergraduate students in Ghana. Asia Pacific Journal of Innovation and Entrepreneurship. https://doi.org/10.1108/APJIE-07-2019-0052

Agbo, A. A., Nzeadibe, T. C., \& Ajaero, C. K. (2012). Happiness in Nigeria: A SocioCultural Analysis Happiness in Nigeria: A Socio-Cultural Analysis. January. https://doi.org/10.1007/978-94-007-2700-7

Ahmed, U., Pahi, M. H., Mozammel, S., \& Umrani, W. A. (2018). Entrepreneurial Intentions Amongst Female Students: Test of a Moderated Model in an Emerging Economy Entrepreneurial Intentions Amongst Female Students : Test of a Moderated Model in An Emerging Economy. The Turkish Online Journal of Design, Art and Communication - TOJDAC, 3080-3091. https://doi.org/10.7456/1080SSE/385

Alabi, F. ., David, J. ., \& Aderinto, O. . (2019). The impact of government policies on business growth of SMEs in South Western Nigeria. International Journal of Management Studies and Social Science Research, 1(2), 1-14.

Alshebami, A. S., Al-jubari, I., Alyoussef, I., \& Raza, M. (2020). Entrepreneurial education as a predicator of community college of Abqaiq students' entrepreneurial intention. Management Science Letters, 10(2020), 3605-3612. https://doi.org/10.5267/j.msl.2020.6.033

Amaliawati, S., Martono, T., Dyah, C., \& Indrawati, S. (2019). The Influence of Entrepreneurship Education on The Business Performance Through Entrepreneurial Intention. International Journal of Educational Research Review, 4(2), 162-171.

Anderson, J. C., \& Gerbing, D. W. (1988). Structural Equation Modeling in Practice: A Review and Recommended Two-Step Approach. Psychological Bulletin, 103(3), 411-423.

Anjum, T., Ramzani, S. R., Farrukh, M., Nazar, N., Raju, V., \& Shahzad, I. A. (2018). Entrepreneurial Intentions of Pakistani Students: The Role of Entrepreneurial Education, Creativity Disposition, Invention Passion \& Passion for Founding. Journal of Management Research, 10(3), 76-100. 
https://doi.org/10.5296/jmr.v10i3.13253

Anjum, T., V, R. B., \& Phung, S. P. (2020). Moderating Role of University Support on the relationship between Effective Entrepreneurship Education and Entrepreneurial Intention. Test Engineering and Management, Volume 83, pp 16377 - 16387.

Asimakopoulos, G., Hernández, V., \& Miguel, J. P. (2019). Entrepreneurial Intention of Engineering Students : The Role of Social Norms and Entrepreneurial Self-E ffi cacy. Sustainability, 11(4314), 1-17. www.mdpi.com/journal/sustainability

Audretsch, D. B. (2007). Entrepreneurship capital and economic growth. Oxford Review of Economic Policy, 23(1), 63-78.

Ayalew, M. M., \& Zeleke, S. A. (2018). Modeling the impact of entrepreneurial attitude on self-employment intention among engineering students in Ethiopia. Journal of Innovation and Entrepreneurship, 7(8), 1-27. http://dx.doi.org/10.1186/s13731-0180088-1

Bazkiaei, H. A., Heng, L. H., Khan, N. U., \& Sauf, R. B. A. (2020). Do entrepreneurial education and big-five personality traits predict entrepreneurial intention among universities students? Do entrepreneurial education and big-five personality traits predict entrepreneurial intention among universities students? Cogent Business \& Management, 7(1), 3-18. https://doi.org/10.1080/23311975.2020.1801217

Boldureanu, G., Ionescu, A. M., Ionescu, A., Boldureanu, D., Bedrule-grigorut, M. V., \& Boldureanu, D. (2020). Entrepreneurship Education through Successful Entrepreneurial Models in Higher Education Institutions. Sustainability, 12(1267), 133.

Bose, T. K., \& Uddin, M. R. (2012). Determinants of Entrepreneurial Intention of Business Students in Bangladesh. International Journal of Business and Management, 7(24), 128-137. https://doi.org/10.5539/ijbm.v7n24p128

Caballero-García, P., Guillén, E., \& Martínez, P. J. (2017). creativity , entrepreneurship and happiness : ingredients for a high education change.Innovation and Entrepreneurship SIE 2017. 
Carrillo, B., \& Montiel, C. (2020). El impacto de la educación en la intención emprendedora : efecto del entorno universitario The impact of entrepreneurship education on entrepreneurial intention : the university. Revista ESPACIOS, 41(39), 250-260.

Chienwattanasook, K., Jermsittiparsert, K., \& Jarinto, K. (2019). The Influence of Entrepreneurial Orientation, Entrepreneurial Education and University Support on the Entrepreneurial Intentions of Thai graduates, with the Moderating role of Culture. International Journal of Innovation, Creativity and Change, 10 (1), 198-220.

Chin, W. W. (1998). The Partial Least Squares Approach to Structural Equation Modeling. Advances in Hospitality and Leisure, April, 295-336.

Chin, W. W. W. (2010). How to write up and report PLS analyses. Handbook ofPpartialLleast squares: Concepts, Methods and Applications, (July), 171-193. https://doi.org/10.1007/978-3-540-32827-8

David, J., \& Lawal, M. C. (2018). Religiosity and Entrepreneurial Intentions in Nigeria Religiosity and Entrepreneurial Intentions in Nigeria. Jurnal Bisnis Dan Manajemen, 8(2), 212-222. https://doi.org/10.15408/ess.v8i2.7331

Doan, X. T., \& Phan, T. T. H. (2020). The impact of entrepreneurial education on entrepreneurial intention: The case of Vietnamese. Management Science Letters, 10(2020), 1787-1796. https://doi.org/10.5267/j.msl.2019.12.040

Edewor, P. A., Imhonopi, D., \& Amusan, T. (2014). Socio-Cultural and Demographic Dynamics in Sustainable Entrepreneurial Development in Nigeria. Developing Country Studies, 4(4), 58-64.

Esfandiar, K., Shari, M., Pratt, S., \& Altinay, L. (2019). Understanding entrepreneurial intentions: A developed integrated structural model approach. Journal of Business Research Journal, 94(2019), 172-182. https://doi.org/10.1016/j.jbusres.2017.10.045

Etikan, I. Musa, S. A., \& Alkassim, R. S. Comparison of convenience sampling and purposive sampling. American journal of theoretical and applied statistics. 5(1) 2016, 1-4. https://doi: 10.11648/j.ajtas.20160501.11

Ezeh, P. C., Nkamnebe, A. D., \& Omodafe, U. P. (2019). Determinants of entrepreneurial 
intention among undergraduates in a Muslim community. Management Research Review. https://doi.org/10.1108/MRR-09-2018-0348

Fini, R., Marzocchi, G. L., \& Sobrero, M. (2009). The Foundation of Entrepreneurial Intention. January, 1-47.

Fragoso, R., Rocha-junior, W., \& Xavier, A. (2019). Determinant factors of entrepreneurial intention among university students Determinant factors of entrepreneurial intention among university students in Brazil and Portugal. Journal of Small Business \& Entrepreneurship, O(0), 1-25. https://doi.org/10.1080/08276331.2018.1551459

Gubik, A. S., \& Farkas, S. (2019). Entrepreneurial intention in the visegrad countries. DANUBE:Law, Economics and Social Issues Review, 10(4), 347-368. https://doi.org/10.2478/danb-2019-0018

Gujrati, R., Tyagi, V., \& Lawan, L. A. (2019). family financial status and students ' entrepreneurial family financial status a nd students ' entrepreneurial intention: the mediatory role of entrepreneurship. Journal of Management, 6(3), 21-28. https://doi.org/10.34218/JOM.6.3.2019.003

Hair, J. F., Anderson, R. E., Tatham, R. L., \& Black, W. C. (1998). Multivariate data analysis. International Journal of Pharmaceutics. https://doi.org/10.1016/j.ijpharm.2011.02.019

Hair, J. F. J., Hult, G. T. M., Ringle, C., \& Sarstedt, M. (2014). A primer on partialLleast squares structural equation modeling (PLS-SEM). Long Range Planning (Vol. 46). Thousand Oaks, CA: SAGE Publications. https://doi.org/10.1016/j.lrp.2013.01.002

Hair, J. F., Black, W. C., Babin, B. J., Anderson, R. E., \& Tatham, R. L. (2010). Multivariate data analysis. Vectors (7th ed.), Vol. 6. Upper Saddle River, NJ: Pearson Prentice Hall Upper Saddle River, NJ. https://doi.org/10.1016/j.ijpharm.2011.02.019

Hair, J. F., Ringle, C. M., \& Sarstedt, M. (2011). PLS-SEM: Indeed aSsilver bullet. The Journal of Marketing Theory and Practice, 19(2), 139-152. https://doi.org/10.2753/MTP10696679190202

Hassana, B. (2015). Entrepreneurship as a viable career choice for Nigerian youth. 
Henseler, J., Ringle, C., \& Sinkovics, R. (2009). The use of partial least squares path modeling in international marketing. Advances in International Marketing, 20, 277319.

Henseler, J., Ringle, C. M., \& Sarstedt, M. (2015). A new criterion for assessing discriminant validity in variance-based structural equation modeling. Journal of the Academy of Marketing Science, 43(1), 115-135. https://doi.org/10.1007/s11747-014-0403-8

Hong, L. M., Sha'ari, M. A. H. A., Wan, F., \& Che, R. (2020). determinant factors that influence entrepreneurial intention determinant factors that influence entrepreneurial. Jurnal Manajemen Dan Kewirausahaan, 22(1), 80-86. https://doi.org/10.9744/jmk.22.1.80

Hussain, A., \& Hashim, N. (2015). Impact of Entrepreneurial Education on Entrepreneurial Intentions of Pakistani Students. Journal of Entrepreneurship and Business Innovation, 2(1), 43-53. https://doi.org/10.5296/jebi.v2i1.7534

Ibrahim, M. A., \& Shariff, M. N. M. (2016). Mediating Role Of Access To Finance On The Relationship Between Strategic Orientation Attributes And Smes Performance In Nigeria. International Journal of Business and Society, 17(3), 473-496.

Ibrahim, N. A., Mahmood, R., \& Bakar, M. S. (2018). Strategic improvisation and HEIs performance: the moderating role of organizational culture. PSU Research Review: An International Journal. Published by Emerald Publishing Limited. https://doi.org/10.1108/PRR-01-2017-0009

Ibrahim, N. A., \& Mas'ud, A. (2016). Moderating role of entrepreneurial orientation on the relationship between entrepreneurial skills, environmental factors and entrepreneurial intention: A PLS approach. Management Science Letters, 6, 225-236. https://doi.org/10.5267/j.msl.2016.1.005

Iakovleva, T., Shirokova, G., \& Tsukanova, T. (2014). Exploring the Relationship between University Context and Entrepreneurial Intentions: Institutional Perspective. 
January, 1-39.

Ismail, A. (2015). The Entrepreneurial Attitude and Intentions of Newly Enrolled University Students - Issues and Policy Implications. Journal of Research in Business, Economics and Management (JRBEM), 4(3), 426-436.

Iwelumo, M. (2018). Micro Pensions - The New Frontier. Journal of Financial Services in Nigeria, April, 11-14.

Jermsittiparsert, K., \& Sriyakul, T. (2019). The Mediating Role of Entrepreneurial Passion in the Relationship between Entrepreneur Education and Entrepreneurial Intention among University Students in Thailand. International Journal of Innovation, Creativity and Change., 6(10), 193-212.

Kakkonen, M.-L. (2018). First- year business students' e ntrepreneurial attitudes. 4th International Conference on Higher Education Advances (HEAd'18), 257-265.

Keilbach, M., Tamvada, J. P., \& Audretsch, D. B. (2008). Sustaining entrepreneurship and economic growth: lessons in policy and industry innovations from Germany and India (Vol. 19). Springer Science \& Business Media.

Kela, N., Icekson, T., \& Peres, T. T.-H. (2019). optimism and entrepreneurial intentions among students: the mediating role of emotional intelligence. Journal of Entrepreneurship Education, 22(4), 1-19.

Khalifa, A. H., \& Dhiaf, M. M. (2016). the impact of entrepreneurship education on entrepreneurial intention: the UAE context. Polish Journal of Management Studies, 14(1), 119-128. https://doi.org/10.17512/pjms.2016.14.1.11

Kim-soon, N., Ahmad, A. R., \& Ibrahim, N. N. (2014). Kim-Soon, N ., Ahmad , A . R ., and Ibrahim , N . N . ( 2014 ). Entrepreneurial Motivation and Entrepreneurship Career Intention: Case at a Malaysian Public Entrepreneurial Motivation and Entrepreneurship Career Intention: Case at a Malaysian Public Un. Crafting Global Competitive Economies: 2020 Vision Strategic Planning \& Smart Implementation Entrepreneurial, November, 1001-1011.

Kusmintarti, A., Asdani, A., \& Riwajanti, I. (2017). The relationship between creativity , 
entrepreneurial attitude and entrepreneurial intention ( case study on the students of State Polytechnic Malang ). International Journal of Trade and Global Markets, 10(1), 28-36. https://doi.org/10.1504/IJTGM.2017.082379

Kusmintarti, A., Thoyib, A., Ashar, K., \& Maskie, G. (2014). The Relationships among Entrepreneurial Characteristics, Entrepreneurial Attitude, and Entrepreneurial Intention The Relationships among Entrepreneurial Characteristics, Entrepreneurial Attitude, and Entrepreneurial Intention. Journal of Business and Management (IOSRJBM), 16(6), 25-32. https://doi.org/10.9790/487X-16622532

Law, K. M. Y., \& Breznik, K. (2016). Impacts of innovativeness and attitude on entrepreneurial intention: among engineering and non-engineering students. International Journal of Technology and Design Education. https://doi.org/10.1007/s10798-016-9373-0

Law, K. M. Y., \& Breznik, K. (2017). Impacts of innovativeness and attitude on entrepreneurial intention: among engineering and non-engineering students. International Journal of Technology and Design Education, October. https://doi.org/10.1007/s10798-016-9373-0

Lawal, T., \& Oluwatoyin, A. (2011). National development in Nigeria: Issues, challenges and prospects. Journal of Public Administration and Policy Research, 3 (November), 237-241. https://doi.org/10.5897/JPAPR11.012

Leng, Y. K., \& Buang, N. A. (2019). 15 Indonesian Journal on Learning and Advanced Education. Indonesian Journal on Learning and Advanced Education, 1(1), 15-25. https://doi.org/10.23917/ijolae.v1i1.7288

Li, L., \& Wu, D. (2019). Entrepreneurial education and students' entrepreneurial intention : does team cooperation matter? Journal of Global Entrepreneurship Research, 9 (35), 1-13. https://doi.org/10.1186/s40497-019-0157-3

Lin, J., \& Sang, D. (2019). How does Entrepreneurial Education Influence the Entrepreneurial Intention of College Students: The Moderating and Mediating Effects of Entrepreneurial Alertness. IJET, 14(8), 139-154. https://doi.org/10.3991/ijet.v14i08.10408 Dapeng 
Liñán, F., Rodríguez-Cohard, J. C., \& Rueda-Cantuche, J. M. (2011). Factors Affecting Entrepreneurial Intention Levels: A Role for Education. International Entrepreneurship and Management Journal, 7, 195-218. https://doi.org/10.1007/s11365-010-0154-z

Lindsay, N. J. (2005). Toward A Cultural Model of Indigenous Entrepreneurial Attitude. Academy of Marketing Science Review, 2005(05).

Liu, X., Lin, C., Zhao, G., \& Zhao, D. (2019). Research on the Effects of Entrepreneurial Education and Entrepreneurial Self-Efficacy on College Students ' Entrepreneurial Intention The Effect of Entrepreneurial Education. Frontiers in Psychology, 10(869), 1-9. https://doi.org/10.3389/fpsyg.2019.00869

Mamun, A. Al, \& Fazal, S. A. (2019). Entrepreneurial knowledge, skills, competencies and performance. Asia Pacific Journal of Innovation and Entrepreneurship, 13(1), 29-48. https://doi.org/10.1108/APJIE-11-2018-0067

Mamun, A. Al, Nawi, N. B. C., Dewiendren, A. A., \& Shamsudin, S. F. F. B. (2016). Examining the Effects of Entrepreneurial Competencies on Students 'Entrepreneurial Intention. Mediterranean Journal of Social Sciences MCSER Publishing, Rome-Italy, 7(2), 119127. https://doi.org/10.5901/mjss.2016.v7n2p119

Mamun, A. Al, Shamsudin, S. F. F. B., Nawi, N. B. C., Nasi, N. A. B., \& Zakaria, M. N. Bin. (2017). Entrepreneurial Education Service Quality , Entrepreneurial Intention, and ‘ Key Performance Indicators ' of Entrepreneurship Education Policies in Malaysia. Advanced Science Letters, 23(9), 8204-8209. https://doi.org/10.1166/asl.2017.9862

Mamuzo, M. O., \& AKPOR-ROBARO. (2012). The impact of socio-cultural environment on entrepreneurial emergence: a theoretical analysis of nigerian society. European Journal of Business and Management, 4(16), 172-183.

Massaro, M., Mas, F. D., Garlatti, A., \& Paschetto, M. (2015). The Effect of Entrepreneurial Intention on new Service Development. 103-111.

Mei, H., Lee, C., \& Xiang, Y. (2020). education sciences Entrepreneurship Education and Students' Entrepreneurial Intention in Higher Education. Education Sciences, 
10(257), 1-18. https://doi.org/10.3390/educsci10090257

Mlouk, A., Cera, G., Cera, E., \& Shumeli, A. (2020). The Impact of Entrepreneurship Education on Entrepreneurial Intention. A Quasi-Experimental Research Design. Journal of Competitiveness, 12(1), 39-56. https://doi.org/10.7441/joc.2020.01.03

Moraes, G. H. S. M. de, Iizuka, E. S., \& Pedro, M. (2018). Effects of Entrepreneurial Characteristics and University Environment on Entrepreneurial Intention. RAC, Rio de Janeiro, 2(2), 226-248. https://doi.org/10.1590/1982-7849rac2018170133

Muhammad, I. G., Muazu, M., \& Ibrahim, N. A. (2017). Mediating Effect Of Entrepreneurial Skills On The Relationship Between Entrepreneurial Orientation And Entrepreneurial. IPBJ, 9(8), 46-62.

Njambi, M. P. (2016). An evaluation of entrepreneurship education as a tool used by the government to promote growth and development of Smes In Kenya a case study of the kpmg top 100 smes. Strathmore University.

Norashidah, \& Hussain, A. (2015). Impact of Entrepreneurial Education on Entrepreneurial Intentions of Pakistani Students. Journal of Entrepreneurship and Business Innovation, 2(1), 43-53.

Norziani, D., Mastura, J., \& Rosdi, M. A. S. (2015a). Attitude and Entrepreneurial Intention Among Rural Community: the Mediating Role of Entrepreneurial Opportunity Recognition. SHS Web of Conferences, 18(01005), 1-9. https://doi.org/10.1051/shsconf/20151801005

Norziani, D., Mastura, J., \& Rosdi, M. S. (2015b). Attitude and Entrepreneurial Intention Among Rural Community: the Mediating Role of Entrepreneurial Opportunity Recognition. SHS Web of Conferences Creating, 18(01005).

Nuseir, M. T., Basheer, M. F., \& Aljumah, A. (2020). Antecedents of entrepreneurial intentions in smart city of Neom Saudi Arabia : Does the entrepreneurial education on artificial intelligence matter? Antecedents of entrepreneurial intentions in smart city of Neom Saudi Arabia : Does the entrepreneurial e. Cogent Business \& Management, 7(1825041), 1-16. https://doi.org/10.1080/23311975.2020.1825041 
Obisi, C., Aderotimi, A., \& Gbadamosi, O. (2016). Nigerian Business Environment Daunting: Challenges and Suggested Solutions. International Journal of Scientific Research in Education, 9 (September), 144-150.

Odii, A., \& Njoku, A. C. (2013). Challenges and Prospects of Entrepreneurship in Nigeria. Academic Journal of Interdisciplinary Studies Published, 2 (5), 25-36. https://doi.org/10.5901/ajis.2012.v2n5p25

Odor, H. O., Martins-Emesom, J. N., \& Bakwuye, C. O. (2019). Entrepreneurship Education and Entrepreneurial Intention Among Students Entrepreneurship Education and Entrepreneurial Intention Among Students of Delta State Polytechnic, Ogwashi Uku , Delta State of Nigeria. European Journal of Business and Management, 11 (20). https://doi.org/10.7176/EJBM

Ohanu, I. B., \& Ogbuanya, T. C. (2018). Determinant factors of entrepreneurship intentions of electronic technology education students in Nigerian universities. Journal of Global Entrepreneurship Research, 8(36), 1-17.

Olukayode, V. (2014). Nigeria's Business Environment: Issues Challenges And Prospects. 4(4), 132-138. https://doi.org/10.6007/IJARBSS/v4-i4/770

Oluwale, B. A., Olaposi, T. O., Adelowo, C. M., \& Akangbe, I. A. (2016). Factors influencing entrepreneurial orientation of smallholder farmers in Southwestern nigeria. FUTA Journal of Management and Technology, 1(2), 123-141.

Onodugo, V., \& Onodugo, C. I. (2015). Impact of socio-cultural factors on entrepreneurial development in Nigeria. African Educational Research Journal, 3(December), 246254.

Paço, A. do, Ferreira, J. M., Raposo, M., Rodrigues, R. G., \& Dinis, A. (2013). Entrepreneurial intentions : is education enough? International Entrepreneurship and Management Journal. https://doi.org/10.1007/s11365-013-0280-5

Pantelitsa, E., ARIANA, P., MARIOS, D., \& GEORGE, K. (2018). Entrepreneurship in Cyprus (Issue December 2018).

Passaro, R., Quinto, I., \& Thomas, A. (2018). The impact of higher education on 
entrepreneurial intention and human capital. Journal of Intellectual Capital, 19(1), 135-156. https://doi.org/10.1108/JIC-04-2017-0056

Patrisia, D., \& Abror, A. (2019). The Entrepreneurial Attitudes of Higher Education Students. Advances in Economics, Business and Management Research, 65, 576-579. https://doi.org/10.2991/icebef-18.2019.123

Pradhan, R. K., \& Nath, P. (2012). Perception of Entrepreneurial Orientation and Emotional Intelligence : A Study on India' s Future Techno-Managers. Global Business Review, 13(1), 89-108. https://doi.org/10.1177/097215091101300106

Pulka, B., Aminu, A. A., \& Rikwentishe, R. (2015). The Effects of Entrepreneurship Education on University Students 'Attitude and Entrepreneurial Intention. European Journal of Business and Management, 7(20), 149-157.

Pulka, B. M., Aminu, A. A., \& Rikwentishe, R. (2015). The Effects of Entrepreneurship Education on University Students ' Attitude and Entrepreneurial Intention. European Journal of Business and Management, 7(20), 149-157.

Purwana, D., \& Suhud, U. (2019). Extending the Shapero' s Model: Entrepreneurial Education Can Predict Entrepreneurial Intention of Vocational School Students? Research Journal of Applied Sciences, 13(2), 150-2018. https://doi.org/10.36478/rjasci.2018.150.156

Purwana, D., Suhud, U., \& Wibowo, S. F. (2018). Determinant Factors of Students' Entrepreneurial Intention: A Com- parative Study. Dinamika Pendidikan, 13(1), 113. https://doi.org/10.15294/dp.v13i1.12971

Radipere, S., \& Ladzani, W. (2014). The effects of entrepreneurial intention on business performance. Journal of Governance and Regulation, 3(4), 210-222.

Ramos, D., Madeira, M. J., \& Duarte, F. A. P. (2020). Entepreneurship Education and Entrepreneurial Intention: the Case of Portugal. Ekonomika Regiona [Economy of Region], 16(1), 157-170.

Rasheed, K. O., \& Aduragbemi, C. (2016). Entrepreneurial Marketing and SMEs Performance in Lagos State, Nigeria. Imperial Journal of Interdisciplinary Research 
(IJIR), 2(1), 98-101.

Ringle, C. M., \& Sinkovics, R. R. (2009). The Use Of Partial Least Squares Path Modeling In International Marketing. Advances in International Marketing, Volume, 20, 277319. https://doi.org/10.1108/S1474-7979(2009)0000020014

Robledo, R., Luis, J., Arán, V., Sanchez, M., Victor, R., \& Molina, M. Á. (2015). The moderating role of gender on entrepreneurial intentions: A TPB perspective. Intangible Capital, 11(1), 92-117. http://dx.doi.org/10.3926/ic.557

Rodrigues, R. G., Marques, P. C. I., \& Geraldes, S. (2020). Understanding entrepreneurial intentions around the World: an empirical approach.Cardernos de Gestao e Empreendedorismo, 8(1), 1-19. https://doi.org/10.32888/cge.v8i1.39903

Ruswanti, E. (2015). Entrepreneurship Knowledge, Training Home Industry, And Attitude Towards Entrepreneurial Intention Enterpreunership. 2nd International Conference on "Global Trends in Academic Research" (GTAR- 2015), 2, 643-654.

Saleem, I., \& Khan, R. (2020). Entrepreneurial intention among female university students : examining the moderating role of entrepreneurial education Entrepreneurial intention among female university students : examining the moderating role of entrepreneurial education. International Business and Entrepreneurship Development, 12(4), 217234.

Sanusi, S. L. (2010). Growth prospects for the nigerian economy.

Saraih, U., Ibnu Ruslan, R., Ali, M. A., \& Mohd Suffian, M. S. Z. (2019). The Impacts of Entrepreneurial Education and Entrepreneurial Implementation on Entrepreneurial Intention: Evidences from Public University in the Northern Malaysia. International Journal of Engineering and Advanced Technology (IJEAT), 8(5C), 354-358. https://doi.org/10.35940/ijeat.E1050.0585C19

Saraih, U. N., \& Ali, M. A. (2019). Understanding The Relationships Between Entrepreneurial Education, Entrepreneurial Implementation and Entrepreneurial Intention: An Empirical Investigation. Asia Proceedings of Social Sciences 4(2), 4(2), 139-142. 
Sekaran, U., \& Bougie, R. (2013). Research methods for business: A skill-building approach, Fourth edition. John Wiley and Sons, New York. Retrieved from http://eu.wiley.com/WileyCDA/WileyTitle/productCd-111994225X.html

Silangen, C., \& Harapan, U. P. (2016). The Effect Of Entrepreneurship Education On Entrepreneurial Intention In Indonesia. DeReMa Jurnal Manajemen, 11(1), 67-86.

Singer, S., Amorós, J. E., \& Arreola, D. M. (2015). Global entrepreneurship monitor: 2014 global report. Global Entrepreneurship Research Association, 1-116.

Soomro, M. A., Memon, M. S., \& Bukhari, N. S. (2019). Entrepreneurial Education and its Impact on Entrepreneurial Intentions: A Comparative Analysis of Business Graduates of Public and Private Universities Pacific Business Review International, 11(6), 35-46.

Sopta, M., Mikić, M., \& Horvatinović, T. (2018). The Role Of Entrepreneurial Education In The Development Of Entrepreneurship. Časopis Za Ekonomiju i Tržišne Komunikacije, viii(ii), 385-395. https://doi.org/10.7251/EMC1802385M

Sultan, M. F., Maqsood, A., \& Shrif, H. M. (2019). Impact of Entrepreneurial Education on Students Entrepreneurial Intentions. KASBIT Business Journal (KBJ, 9, 131-153.

Tiwari, P., Bhat, A. K., \& Tikoria, J. (2020). Mediating Role of Prosocial Motivation in Predicting Social Entrepreneurial Mediating Role of Prosocial Motivation in Predicting Social Entrepreneurial Intentions. Journal of Social Entrepreneurship, 124. https://doi.org/10.1080/19420676.2020.1755993

Tung, L. O. C. (2011). The impact of entrepreneurship education on entrepreneurial intention of engineering students. Cityu University Of Hong Kong.

Velásquez, J. adolfo T., Arias, aleJandro V., Hernández, J. B., Díez-echaVarría, luisa fernanda, Marín, maría lucelly urrego, \& Pérez, fausTo orlando maussa. (2017). Characterization of entrepreneurial intention in university students as from Systemic Entrepreneurship Intention Model : A case study Characterization of entrepreneurial intention in university students as from Systemic Entrepreneurship Intention Model : Cuadernos de Gestion, November, 1-19. https://doi.org/10.5295/cdg.160670jt 
Viana, A. B. N., Carvalho, L. C., \& Cândido, R. B. (2019). Entrepreneurial Intentions of Management Students: A Study Applied to an E-Learning University. In L. C. Carvalho \& A. D. Daniel (Eds.), Global Considerations in Entrepreneurship Education and Training: Vol. $i$ (pp. 1-17).

vixathep, S. (2014). Entrepreneurship, Government Policy and Performance of SMEs in Laos. 28, 1-21.

Voda, A. I., Covatariu, D., \& Ghiuță, O.-A. (2019). Student' s entrepreneurial intentions : role of entrepreneurial education and risk taken ability. Environmental Engineering and Management Journal, 18(7), 1527-1534. https://doi.org/10.30638/eemj.2019.143

Williams, N., Vorley, T., \& Ketikidis, P. (2013). Economic resilience and entrepreneurship: A case study of the Thessaloniki City Region. Local Economy, Volume: 28 issue: 4, page(s): 399-415. https://doi.org/10.1177/0269094213475993

Wyk, R. Van, Boshoff, A., \& Bester, C. (2003). Entrepreneurial Attitudes : Sources? What are Their Sources? SAJEMS NS, 6(1), 1-24.

Zeleam, T., Temtime, T., \& Pansiri, J. (2004). Small business critical success/failure factors in developing economies: Some evidence from Botswana. Gaborone: University of Botswana.

Zhang, Y., Duysters, G., \& Cloodt, M. (2014). The role of entrepreneurship education as a predictor of university students ' entrepreneurial intention. Int Entrep Manag J, 10, 623-641. https://doi.org/10.1007/s11365-012-0246-z

Zhao, J., Wei, G., Chen, K., \& Yien, J. (2020). Psychological Capital and University Students Entrepreneurial Intention in China: Mediation Effect of Entrepreneurial Capitals. Frontiers $\quad$ Psychology, $10(2984), \quad 1-11$. https://doi.org/10.3389/fpsyg.2019.02984 